\title{
Maps, Tables, and Figures
}

Map 1 Tlaxcala-Puebla Region xi

Map 2 The City of Puebla de los Angeles, 1691 xii

Table 1 Indigenous governors of Tlaxcala, 1599-1717 28

Table 2 Indigenous governors of Puebla to 1692

Figure 1 Annals of Puebla, f. 13, 1668-1669 66

Figure 2 Annals of Tlaxcala, ff. 11v-12, 1534-1543 156 